\title{
Distribution and risk appraisal of dissolved trace elements in Begnas Lake and Rupa Lake, Gandaki Province, Nepal
}

\author{
Ramesh Raj Pant ${ }^{1} \cdot$ Kiran Bishwakarma $^{2,3} \cdot$ Buddha Bahadur Basnet $^{4} \cdot$ Khadka Bahadur Pal $^{5} \cdot$ Laxmi Karki $^{1}$. \\ Yam Prasad Dhital ${ }^{6} \cdot$ Youb Raj Bhatta ${ }^{1}$ Bhoj Raj Pant ${ }^{4} \cdot$ Lal B. Thapa $^{7}$
}

Received: 29 November 2020 / Accepted: 17 March 2021 / Published online: 6 April 2021

(C) The Author(s) 2021 OPEN

\begin{abstract}
Contamination of the trace elements (TEs) in the freshwater ecosystems is becoming a worldwide problem. This study was carried out to investigate the TEs contamination, and their associated health risk in Begnas Lake and Rupa Lake, Gandaki Province, Nepal. A total of 30 water samples were collected from both lakes during the pre-monsoon season in 2016. The samples were analyzed for the TEs including copper (Cu), lead (Pb), zinc ( $\mathrm{Zn}$ ), nickel (Ni), cobalt (Co), chromium $(\mathrm{Cr})$, cadmium (Cd), manganese (Mn), cesium (Cs), and arsenic (As) using inductively coupled plasma mass spectrometry. The results exhibited that the mean concentrations of all the TEs were higher in Rupa Lake as compared to Begnas Lake except $\mathrm{Pb}$. Principal component analysis and cluster analysis revealed that both the geogenic and anthropic sources were the major contributors of TEs in the lake water. Anthropic activities were considered to contribute the TEs like Zn and $\mathrm{Mn}$ in lake water mainly via agricultural runoff, while evaluating the risk of TEs on human health all the elements showed $\mathrm{HQ}<1$ and $\mathrm{CR}<10^{-4}$ indicating currently very low health risk concerns. In good agreement with above, the water quality index (WQI) of the Begnas Lake and Rupa Lake was 2.67 and 5.66, respectively, specifying the lake water was safe for drinking and public health concern. This appraisal would help the policymakers and concerned stakeholders for the sustainable management of Ramsar listed freshwater lakes in the Himalayas.
\end{abstract}

Keywords Trace elements · Water quality · Health risk assessment · Hazard quotient · Gandaki Province · Nepal

\section{Introduction}

Contamination of freshwater with toxic trace elements (TEs) due to natural processes such as atmospheric accumulation, geological weathering as well as anthropic activities such as domestic and urban sewerages, industrial effluents, and agro-runoff is of great concern worldwide [1]. The freshwater lakes are susceptible to chemical contaminations as they are stagnant in nature [2]-[5]. The TEs such as arsenic (As), cadmium (Cd), cobalt (Co), chromium
$(\mathrm{Cr})$, cesium $(\mathrm{Cs})$, copper $(\mathrm{Cu})$, manganese $(\mathrm{Mn})$, nickel $(\mathrm{Ni})$, lead $(\mathrm{Pb})$, and zinc $(\mathrm{Zn})$ are the major contaminants having significant toxicity to the human health if their concentrations exceed the desirable limits [6, 7]. The As, Cd, Cr, $\mathrm{Pb}$, and $\mathrm{Zn}$ have both carcinogenic and non-carcinogenic risks to public health. For instance, $\mathrm{Pb}$ interrupts the gonad secretions [8] and $\mathrm{Zn}$ can damage the digestive, nervous, and blood circulation system in the human [9]. Similarly, excessive concentration of $\mathrm{Cu}$ affects the digestive system, liver, and brain [10]. Thus, the appraisal of TEs and their

$\triangle$ Buddha Bahadur Basnet, budbsn.btechnep@gmail.com | 'Central Department of Environmental Science, Tribhuvan University, Kathmandu, Nepal. ${ }^{2}$ Key Laboratory of Tibetan Environment Changes and Land Surface Processes, Institute of Tibetan Plateau Research, Chinese Academy of Sciences, Beijing 100101, China. ${ }^{3}$ University of Chinese Academy of Sciences, Beijing 100049, China. ${ }^{4}$ Faculty of Science, Nepal Academy of Science and Technology, Lalitpur, Nepal. ${ }^{5}$ Tri-Chandra Multiple Campus, Tribhuvan University, Kathmandu, Nepal. ${ }^{6}$ Institute of Eco-Chongmimg, Faculty of Earth Sciences, East China Normal University, Shanghai, China. ${ }^{7}$ Central Department of Botany, Tribhuvan University, Kathmandu, Nepal. 
associated potential risks in lake water quality is imperative from a human and ecological health perspective [11, 12].

Prior studies have highlighted that the consumption of contaminated water with elevated concentrations of TEs may cause multiple health issues including cancer [13]-[16]. The freshwater lakes in the Himalaya are quite sensitive toward the TEs contamination and, thus, intensive scientific investigations have been carried out in the headwater region of the Tibetan Plateau [17]-[20]. However, in the central Himalayan region, the characterization and health risk appraisal of the TEs contamination on the freshwater bodies are limited [21]. Long-range transport of TEs has been highlighted as one of the major sources of contamination in the glacier-fed water resources in the Himalayas [4]. Additionally, the more recent studies have underlined that the melt-water region in the Himalaya, lowland, and urban areas are found to be relatively more susceptible to TEs contamination due to global climate change and anthropic activities including rampant settlements, industrializations, and modern agriculture $[9,22$, 23].

The freshwater lakes are the main sources of drinking and irrigational water supply in Nepal; however, their quality appraisal is in the primitive stage $[24,25]$. The Begnas Lake and Rupa Lake are located in the central Himalayas, having high anthropic disturbances in the vicinity, especially due to agro-runoff, fisheries, municipal wastes, boating, and religious activities, etc. Majorities of the studies have focused on the water quality, limnological, phytoplankton, macrophytes, and zooplankton investigations in these lakes $[2,26]$. However, to our best knowledge, there is no scientific literature on health risk assessment of TEs in the lake water. The objective of this study is to assess the status of TEs, and their potential human health risk with hazard quotients and carcinogenic risk in the Ramsar listed Begnas Lake and Rupa Lake of the Gandaki Province, Nepal.

\section{Material and methods}

\subsection{Study area}

The Begnas Lake and Rupa Lake are situated in the Gandaki Province, Nepal. These lakes play a vital role in the livelihood stability of the people and ecological sustainability. The Begnas Lake lies at an altitude of 650 m.a.s.l. about $13 \mathrm{~km}$ east of core-urban Pokhara city. The catchment of the lake occupies an area of about $20 \mathrm{~km}^{2}$ in between the Greater Himalaya and the Mahabharat range ( $28.13 \mathrm{~N}$ to $28.21 \mathrm{~N}$ and $84.08 \mathrm{E}$ to $84.17 \mathrm{E}$ ). The lake covers the surface area of $3.28 \mathrm{~km}^{2}$ and the depth ranges from $6.6 \mathrm{~m}$ to $10 \mathrm{~m}$.
The northern side of the lake is far from urban settlements with dominant agro-practices.

Similarly, the catchment area of the Rupa Lake is located in the eastern part of the Pokhara Metropolitan City ( $28.14 \mathrm{~N}$ to $28.20 \mathrm{~N}$ and $84.10 \mathrm{E}$ to $84.17 \mathrm{E}$, elevation 600 m.a.s.l.). The surface area of the lake is $1.35 \mathrm{~km}^{2}$ with an average depth of $3 \mathrm{~m}$.

Both the lakes are located in the subtropical climatic region. The annual temperatures range from $12{ }^{\circ} \mathrm{C}$ to $29^{\circ} \mathrm{C}$ and the rainfall occurs more than $80 \%$ during the monsoon season from June to September [27]. The geology of the Began and Rupa basins is characterized by an intermontane fluvial basin. The basins consist of loamy to sandy gravel, silt, and clay deposits of quaternary age brought from the Annapurna mountain range $[28,29]$. Precambrian to Palaeozoic talc-rich red phyllite, schist, limestone, quartzite, gneiss, and carbonaceous conglomerate with inter-bedded schist are the major geological formations in the region. Due to the presence of the soluble calcareous material in the clastic sediments of the lake basins, the karst structures like subsurface flow channels, cavities; sinkholes, pinnacles, solution chimneys, etc., are widely developed at the surface and underground in both the lake basins [30]. The lakes are surrounded by forest having Shorea robusta, Engelhardtia spicata, Syzygium spp., Lagerstromia spp., and Phyllanthus emblica as the major tree species [26]. Both the lakes are designated as the Ramsar site (No. 2257) in 2016 along with other lake clusters of Pokhara valley.

\subsection{Sampling and analytical methods}

In this study, water samples were collected from 30 different sites from both the lakes ( 15 from each lake) during pre-monsoon season in 2016. The sampling sites were selected on the basis of hydroclimatic conditions, topographic variations, and land-use features. Samples were collected in acid-washed $20-\mathrm{mL}$ ultra-clean high-density polyethylene (HDPE) bottles and stored in a refrigerator at $4{ }^{\circ} \mathrm{C}$ until further analysis. To avoid the adsorption of TEs on the wall of the bottles, the samples were acidified $(\mathrm{pH}<2)$ by using concentrated ultrapure nitric acid. A total of 10 TEs, namely $\mathrm{Cu}, \mathrm{Pb}, \mathrm{Zn}, \mathrm{Ni}, \mathrm{Co}, \mathrm{Cr}, \mathrm{Cd}, \mathrm{Mn}, \mathrm{Cs}$, and As, were analyzed using inductively coupled plasma-mass spectrometry (ICP-MS, X-7 Thermo Elemental) at Institute of Tibetan Plateau Research, Chinese Academy of Sciences (ITP_CAS), Beijing, China, and data processing methods were explained elsewhere [22]. The accuracy of the analytical protocol was ascertained based on repeated measurement of the externally certified reference solution, showing the analytical precision $<5 \%$ [31]. 


\subsection{Statistical analysis}

Multivariate statistical techniques were used for the evaluation and interpretation of the TEs dataset. Spearman's rank correlation was used to assess the potential associations between the TEs as data were not normally distributed [32]. Hierarchical agglomerative cluster analysis (CA) was performed to assess the variability of the TEs on the dataset and to group the similar sampling sites [33,34]. Also, principal component analysis (PCA) was applied to identify the potential pollutants' sources in the lake water [35].

\subsection{Water quality index (WQI)}

The WQI has been widely used in recent years for the water quality assessment $[23,36,37]$. In this study, to assess the WQI of lake water using TEs, the weight of each TEs (Wi) was assigned according to the relative significance of the elements [1]. Nine elements (except $\mathrm{Cs}$ ) were chosen to analyze the WQI. Among them, $\mathrm{Pb}, \mathrm{Cd}$, and $\mathrm{Cr}$; and $\mathrm{Ni}$ and $\mathrm{Zn}$ were given the highest and the lowest ranking, respectively, based on their potential health effect [23]. The WQI was calculated using Eqs. (1) and (2):

$W Q I=\sum_{i=1}^{n} W i \times\left(\frac{C i}{S i}\right) \times 100$

where the relevant weightage $\left(W_{i}\right)$ of each parameter is calculated as:

$W i=w i / \sum_{i=1}^{n} w i$

wi: the weight of each parameter, $\Sigma$ wi: the sum of the weightings of all parameters, $\mathrm{Ci}$ : concentration of each TE in each water sample, and Si:World Health Organization Guidelines for Drinking Water [38] for each TE.

The WQI is classified into five different categories: excellent (WQI<50), good (WQI =50-100), permissible $(W Q I=100-200)$, poor $(W Q I=200-300)$, and very poor (WQI > 300) $[23,39,40]$.

\subsection{Metal index (MI)}

The metal index (MI) was calculated for TEs using maximum allowable concentration (MAC) of elements in drinking water guidelines, which accounts for TEs with possible effects on human health $[9,41]$. The MI was calculated using Eq. (3):

$\mathrm{MI}=\sum\left(\frac{\mathrm{C}}{\mathrm{MAC}}\right)$

C: average concentration of TEs.
The $\mathrm{Ml}>1$ is considered as polluted and, thus, cannot be used for drinking purposes [9].

\subsection{Health risk assessment (HRA)}

The methodology for the assessment of public health risk due to contamination of TEs in drinking water has been described in previous studies [41]-[43]. The major pathways of TEs exposure to human health are ingestion, inhalation, and dermal absorption. The exposure dose for ingestion and dermal absorption were calculated using Eqs. (4) and (5):

$A D D i=\frac{C \times \mathrm{IR} \times \mathrm{EF} \times \mathrm{ED}}{\mathrm{BW} \times \mathrm{AT}}$

$A D D d=\frac{C \times S A \times K p \times E T \times E F \times E D \times C F}{B W \times A T}$

where $A D D_{i}$ is the exposure dose through the ingestion of water, $A D D_{d}$ is the dermal absorption ( $\mathrm{mg} / \mathrm{kg} /$ day), $C$ indicates the average concentration of TEs in water $(\mathrm{mg} / \mathrm{L}), I R$ is the ingestion rate ( $2.5 \mathrm{~L} /$ day), $E F$ is the exposure frequency (350 days/year assuming that the local people spend the remaining 15 days outside from the study site), ED represents the exposure duration ( 68 years, 23,800 days), $B W$ is the average body weight $(65 \mathrm{~kg}), A T$ is the averaging time (in days), $S A$ is the exposed skin area $\left(17,000 \mathrm{~cm}^{2}\right), K p$ is the skin permeability coefficient in water $(\mathrm{cm} / \mathrm{h}), E T$ is the exposure time spent in bathing and shower $(0.6 \mathrm{~h} /$ day), and $C F$ is the unit conversion factor $\left(1 \mathrm{~L} / 1,000 \mathrm{~cm}^{3}\right)$. In this study, the skin permeability coefficients in lake water were assumed to be $0.001,0.0006,0.002$, and 0.0002 for As, Mn, $\mathrm{Cu}$, and $\mathrm{Cd}$; $\mathrm{Zn}$ and $\mathrm{Cr}$; $\mathrm{Co}$ and $\mathrm{Pb}$; and $\mathrm{Ni}$, respectively (Tripathee et al., 2016; Wu et al., 2009). The characterization of non-carcinogenic risks such as hazard quotients (HQ) and hazard index (HI) was carried out using US EPA guideline (2004). The HI from both the dermal absorption and ingestion was calculated using Eqs. (6) and (7):

HQingestion $=\frac{A D D}{R f D}$

HQdermal $=\frac{A D D}{\operatorname{RfD}}$

where TEs toxicity reference dose (RfD) is $0.0003 \mathrm{mg} /$ kg-day.

The health risk is considered when the $\mathrm{HQ}$ values are $>1$ [44]. To evaluate the total potential non-carcinogenic risks posed by more than one pathway, $\mathrm{HI}$ is applied for assessing the general tendency for the non-carcinogenic effects and is calculated using Eq. (8): 
$\mathrm{HI}=\mathrm{HQ}_{\text {ingestion }}+\mathrm{HQ}_{\text {dermal }}$

\subsection{Cancer risk (CR)}

CR is the probability that people will develop cancer during their lifetime because of the exposure to toxic chemicals under specific scenarios [45]. The CR of $\mathrm{As}, \mathrm{Cd}, \mathrm{Pb}$, and Cr was calculated as according to Equations (9), (10) and (11):

$\mathrm{CR}_{\text {ingestion }}=\mathrm{ADDi} / \mathrm{CSF}$

$C R_{\text {dermal }}=A D D d / C S F$

And the cancer index $(\mathrm{Cl})$ was calculated as:

$C l=C R_{\text {ingestion }}+C R_{\text {dermal }}$

Here, CSF is the carcinogenic factor $(1.5 \mathrm{mg} / \mathrm{kg} /$ day obtained from US EPA Guideline (2004)).

\section{Results and discussion}

\subsection{General characteristics of TEs}

The statistical summary of TEs (As, Cd, Co, Cr, Cs, Cu, Mn, $\mathrm{Ni}, \mathrm{Pb}$, and $\mathrm{Zn}$ ) of Begnas Lake and Rupa Lake is presented in Table 1. and Fig. 1. In Rupa Lake, the concentration of $\mathrm{Zn}, \mathrm{Mn}$, and $\mathrm{Cu}$ exhibited a maximum variation with a high standard deviation. Nevertheless, the average concentration of the TEs was in the dominance order of $\mathrm{Zn}>\mathrm{Mn}>$ $\mathrm{Cu}>\mathrm{As}>\mathrm{Cr}>\mathrm{Pb}>\mathrm{Ni}>\mathrm{Cs}>\mathrm{Co}>\mathrm{Cd}$. Based on the mean values, the TEs in the lake water can be divided into three groups [22]: (a) Zn (concentration > $10 \mu \mathrm{g} / \mathrm{L}$ ); (b) Mn, As, and $\mathrm{Cu}$ (concentrations 1-10 $\mu \mathrm{g} / \mathrm{L}$ ); and (c) Ni, Cr, Cd, Cs, $\mathrm{Cs}, \mathrm{Co}$, and $\mathrm{Pb}$ (concentration $<1 \mu \mathrm{g} / \mathrm{L}$ ). The relatively high concentration of $\mathrm{Zn}$ might be due to the geogenic process and anthropic activities including agro-runoff.
Similarly, the average concentration of TEs in the Begnas Lake was in the dominancy order of $\mathrm{Zn}>\mathrm{Mn}>\mathrm{Cu}$ $>\mathrm{As}>\mathrm{Pb}>\mathrm{Cr}>\mathrm{Ni}>\mathrm{Co}>\mathrm{Cs}>\mathrm{Cd}$. In the lake, the TEs variation was less noticeable (except Zn) (Fig. 2). The increased concentration of $\mathrm{Zn}$ may be due to the intense farming activities in the vicinity of this lake also. Based on mean values, TEs can be categorized into two groups: (a) Zn, Mn, and $\mathrm{Cu}$ (concentrations 1-10 $\mu \mathrm{g} / \mathrm{L}$ ); (b) Cd, Co, Cr, Ni, Pb, As, and Cs (concentrations $<1 \mu \mathrm{g} / \mathrm{L}$ ).

The concentrations of all the elements were more or less the same in both the lakes except As, Mn, and $\mathrm{Zn}$ (Fig. 2). Precisely, the mean concentrations of As, Mn, and Zn were 1.54, 1.90, and 3.70 times higher, respectively, in the Rupa Lake than the Begnas Lake. The As and Mn are the sensitive redox elements, and both are highly soluble in aqueous brines in the divalent form due to the formation of stable chloride complexes. Such contaminants are released from the anthropic activities including a poultry farm, additives, pesticide, and major source of $\mathrm{Zn}$ in the lake water could be the agricultural practices in the lake vicinity [8]. Thus, discharge of agricultural effluents and domestic sewage to the lakes might have increased the concentrations of As, Mn, and Zn.

In the Begnas Lake, the TEs concentrations range between 0.01 and $3.53 \mu \mathrm{g} / \mathrm{L}$, whereas the concentrations in Rupa Lake range between 0.01 and $13.06 \mu \mathrm{g} / \mathrm{L}$. In the case of Rupa Lake, As and Ni concentrations were higher than that of the global mean value. The concentrations of the elements in both the lakes are compared with World Health Organization guidelines (WHO), US EPA, and the global mean value (Table 2). The average concentrations of all the TEs in both the lakes were within the guidelines values for drinking purposes. This indicates that the TEs are mostly derived from the geogenic weathering process. $\mathrm{Cu}$ concentrations of both the lakes were similar to Gosainkunda Lake [4], while the concentrations of the other TEs were comparable with the other lakes and rivers from the Himalayan region (Table 2). The mean concentration of TEs within the standards and comparable to the global level indicating that their concentrations may not be harmful
Table 1 General statistics of TEs in Begnas Lake and Rupa Lake, Pokhara Valley, Nepal (concentration of the TEs is expressed in $\mu \mathrm{g} / \mathrm{L}$ )

\begin{tabular}{llllllllllll}
\hline Lakes & As & $\mathrm{Cd}$ & $\mathrm{Co}$ & $\mathrm{Cr}$ & $\mathrm{Cs}$ & $\mathrm{Cu}$ & $\mathrm{Mn}$ & $\mathrm{Ni}$ & $\mathrm{Pb}$ & $\mathrm{Zn}$ \\
\hline Begnas Lake & Min & 0.79 & $\mathrm{BD}$ & 0.02 & 0.26 & 0.01 & 0.41 & 1.30 & 0.14 & 0.18 & 2.05 \\
& Max & 0.95 & 0.01 & 0.06 & 0.92 & 0.04 & 4.95 & 7.52 & 0.50 & 2.38 & 6.65 \\
& Mean & 0.87 & 0.01 & 0.03 & 0.45 & 0.02 & 1.70 & 2.98 & 0.27 & 0.61 & 3.53 \\
& SD & 0.05 & 0.00 & 0.01 & 0.20 & 0.01 & 1.54 & 1.71 & 0.13 & 0.72 & 1.50 \\
Rupa Lake & Min & 1.14 & $\mathrm{BD}$ & 0.04 & 0.44 & 0.01 & 0.53 & 2.08 & 0.21 & 0.19 & 2.94 \\
& Max & 1.56 & 0.03 & 0.15 & 0.95 & 0.35 & 5.44 & 15.50 & 0.69 & 1.04 & 47.55 \\
& Mean & 1.34 & 0.01 & 0.06 & 0.58 & 0.09 & 1.81 & 5.67 & 0.37 & 0.48 & 13.06 \\
& SD & 0.14 & 0.01 & 0.03 & 0.13 & 0.11 & 1.55 & 4.36 & 0.17 & 0.22 & 14.83 \\
\hline
\end{tabular}

$B D$ Below detection limit 
to the human beings and aquatic environment at present. However, attention should be given to the increasing anthropic activities such as use of excessive pesticides, growing urbanization which might exceed the contaminants in future, causing risks of the harmful effects to the aquatic environment as well as human health.

\subsection{Hierarchical clustering analysis (HCA)}

The contaminated sites were identified with the help of a dendrogram (Figs. 3 and 4). In the Begnas Lake, CA showed three major clusters, namely Clusters 1, 2, and 3 comprising $73.33 \%, 6.67 \%$, and $20 \%$ sampling points, respectively. Clusters 1 and 2 have more or less comparable concentrations of TEs to each other except $\mathrm{Mn}$. The elevated concentration of $\mathrm{Mn}$ in Cluster 2 could be due to the anthropic sources. The dataset showed that Cluster 3 was relatively more contaminated especially by $\mathrm{Cr}, \mathrm{Cu}, \mathrm{Pb}$, and $\mathrm{Zn}$. All these TEs ascribed their anthropic sources which could be due to agricultural runoff and domestic wastes.

Similarly, two distinct clusters were observed in Rupa Lake (Fig. 4) with $13.33 \%$ and $86.66 \%$ sampling points in Cluster 1 and 2, respectively. Results suggested that a notable spatial variation between the clusters in terms of $\mathrm{Cu}, \mathrm{Zn}$, and $\mathrm{Mn}$. Based on the mean concentrations, $\mathrm{Cu}$ and $\mathrm{Zn}$ were 4.30 and 6.13 times higher, whereas $\mathrm{Mn}$ was 2.38 times lower in Cluster 1 as compared to Cluster 2. Thus, from both the clusters, it is deduced that the major sources of TEs in both the lakes were geogenic with minor anthropic signature. The sources of the elevated concentrations of $\mathrm{Cr}, \mathrm{Cu}, \mathrm{Mn}, \mathrm{Pb}$, and $\mathrm{Zn}$ are the agro-runoff and urban settlement areas around the lakes.
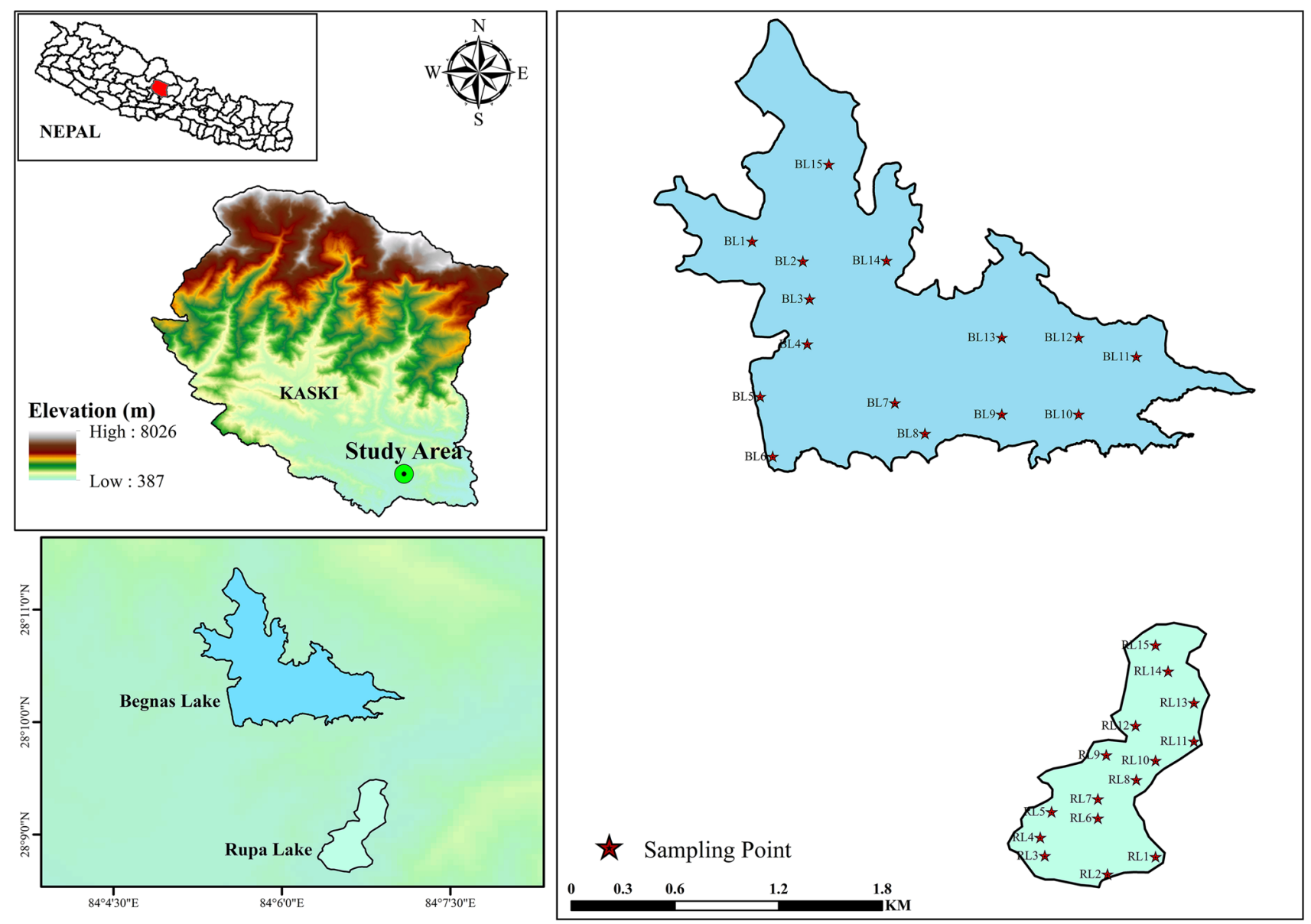

Fig. 1 Sampling points in the Begnas Lake and Rupa Lake, Gandaki Province, Nepal 


\subsection{Principal component analysis and correlation matrices}

Principal component analysis (PCA) reduces the dimensionality of the dataset and one of the most powerful multivariate statistical tools to interpret the sources of TEs [32]. The PCA output of the TEs (As, Pb, Co, Mn, Cs, $\mathrm{Ni}, \mathrm{Cr}, \mathrm{Cu}, \mathrm{Zn}$, and $\mathrm{Cd}$ ) is presented in Fig. 5 and Table 3. Before the analysis, the Kaiser-Meyer-Olkin (KMO) and Bartlett's sphericity tests were performed to examine the validity of PCA. The components are classified as strong, moderate, and weak corresponding to absolute loading values of $>0.75,0.75-0.50$, and $<0.50$, respectively. These strong and moderate associations among the TEs were considered to have a major influence on the lake water quality [46].

In the Begnas Lake, two principal components (PCs) with eigenvalue $>1$, explained about $76.32 \%$ of the total variances. Here, PC1 accounting for $65.36 \%$ of the total variance had strong positive loadings on $\mathrm{Co}, \mathrm{Cr}, \mathrm{Cu}, \mathrm{Ni}, \mathrm{Pb}$, and $\mathrm{Zn}$. The co-location of these TEs is likely to indicate the common sources and appeared to be more connected with anthropic activities. PC2 explains $10.96 \%$ of the total variance, had strong positive loadings on $\mathrm{Mn}$, strong negative loading on As, moderate positive loadings on $\mathrm{Cs}$, and weak positive loadings on $\mathrm{Cd}$. The co-location of these TEs indicated the geological and lithological sources.

The Spearman's rank correlation matrix of Begnas Lake is illustrated in Table 4. A strong correlation between $\mathrm{Ni}-\mathrm{Cr}$; $\mathrm{Ni}-\mathrm{Cu} ; \mathrm{Zn}-\mathrm{Cr} ; \mathrm{Zn}-\mathrm{Cu}$ and $\mathrm{Zn}-\mathrm{Ni}$ pairs $(p<0.01)$ indicated that they are originated from both geogenic and anthropic sources. Moreover, the moderate correlation between $\mathrm{Cr}-\mathrm{Co}$; $\mathrm{Cu}-\mathrm{Co}$; $\mathrm{Cu}-\mathrm{Cr}$; Mn-Co; $\mathrm{Ni}-\mathrm{Co}$; $\mathrm{Pb}-\mathrm{Cr}$; Pb-Cu; $\mathrm{Pb}-\mathrm{Ni}$ and $\mathrm{Pb}-\mathrm{Zn}$ pairs $(p<0.05)$ indicated that they are mainly originated from geogenic sources.
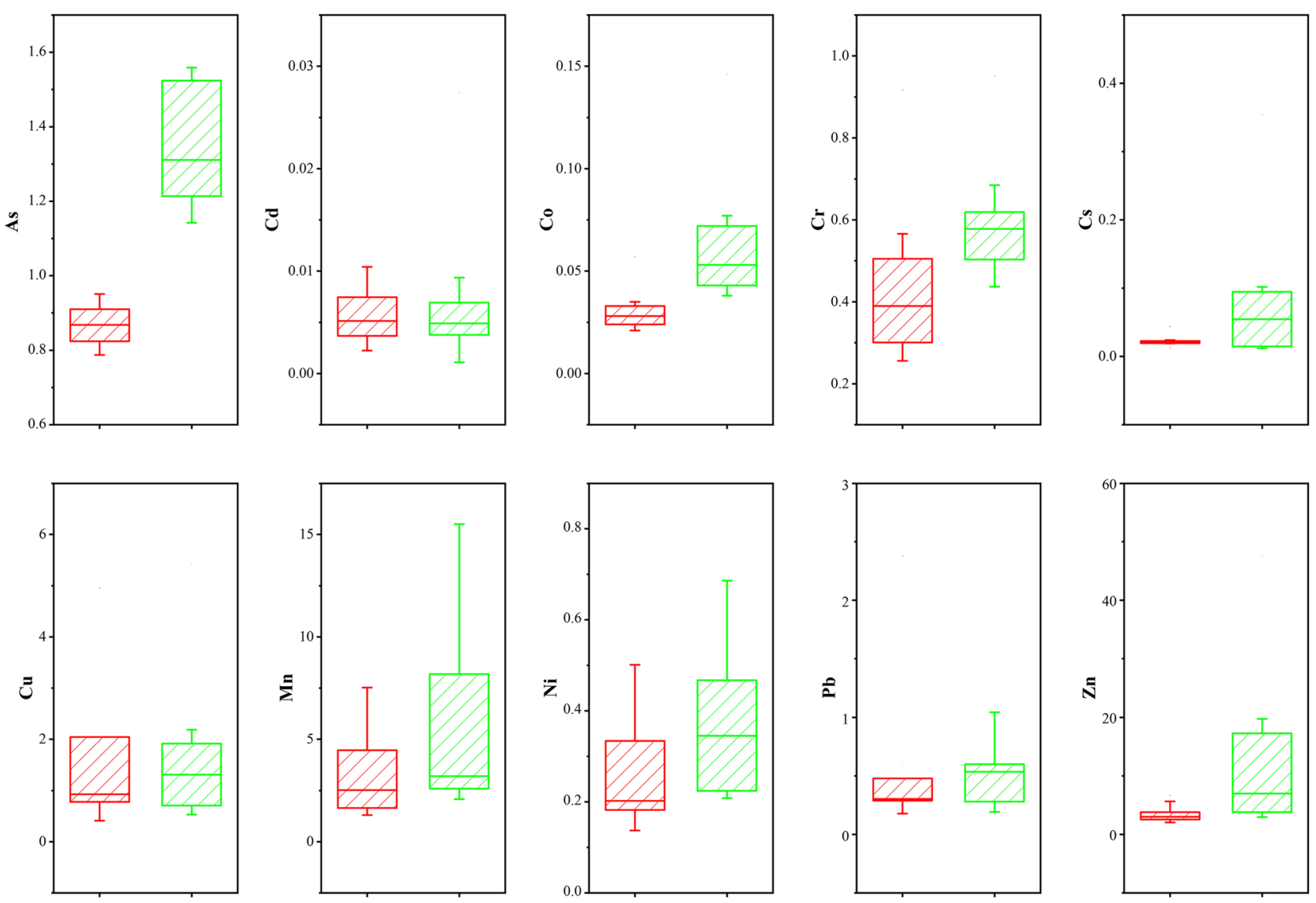

Begnas Lake

Rupa Lake

Fig. 2 Comparison of trace elements (TEs) concentration between Begnas Lake and Rupa Lake, GandakiProvince, Nepal (concentration of the TEs are expressed in $\mu \mathrm{g} / \mathrm{L}$ ) 
Table 2 Comparison of trace elements (TEs) in Begnas Lake and Rupa Lake, Gandaki Province, Nepal, comparison with other study, drinking water guidelines and other continental average value (concentration of the TEs is expressed in $\mu \mathrm{g} / \mathrm{L}$ )

\begin{tabular}{|c|c|c|c|c|c|c|c|c|c|c|}
\hline Lakes & As & $\mathrm{Cd}$ & Co & $\mathrm{Cr}$ & Cs & $\mathrm{Cu}$ & $\mathrm{Mn}$ & $\mathrm{Ni}$ & $\mathrm{Pb}$ & $\mathrm{Zn}$ \\
\hline Begnas lake & 0.87 & 0.01 & 0.03 & 0.45 & 0.02 & 1.7 & 2.98 & 0.27 & 0.61 & 3.53 \\
\hline Rupa lake & 1.34 & 0.01 & 0.06 & 0.58 & 0.09 & 1.81 & 5.67 & 0.37 & 0.48 & 13.06 \\
\hline Phewa lake $^{1}$ & - & 0.003 & 1.44 & 0.71 & - & 0.3 & 393.88 & 0.28 & 0.16 & 4.55 \\
\hline $\begin{array}{l}\text { Gosainkunda } \\
\text { lake }^{1}\end{array}$ & - & 0.002 & 0.11 & 0.21 & - & 1.76 & 4.03 & 0.76 & 0.65 & 13.79 \\
\hline Gandaki river $^{2}$ & - & 0.01 & 0.15 & 4.98 & - & 1.06 & 3.77 & 0.67 & 0.11 & 4.47 \\
\hline Indravati river ${ }^{3}$ & - & - & 0.02 & 0.43 & - & 3.38 & 11.3 & 2.42 & 0.93 & 11.28 \\
\hline Dudhkoshi river ${ }^{3}$ & - & - & 0.01 & 0.8 & - & 2.21 & 25.28 & - & 2.19 & 19.2 \\
\hline Bagmati river ${ }^{4}$ & - & - & 0.38 & 0.58 & - & 11.29 & 158.71 & 2.18 & & 37.05 \\
\hline $\begin{array}{l}\text { Nepalese } \\
\text { standard }^{5}\end{array}$ & 50 & 3 & - & 50 & - & - & 200 & - & 10 & 3000 \\
\hline WHO limits ${ }^{6}$ & 10 & - & 50 & - & - & 2000 & 400 & 70 & 15 & 3000 \\
\hline Global Mean ${ }^{7}$ & 0.62 & 0.08 & 0.14 & 0.07 & 0.01 & - & 34 & 0.8 & 0.08 & 0.6 \\
\hline Asia mean ${ }^{7}$ & $0.15-2.0$ & $\begin{array}{r}0.0089- \\
0.0038\end{array}$ & 0.01 & - & - & $0.76-0.91$ & $0.55-2.2$ & $0.30-1.42$ & - & $\begin{array}{c}0.039- \\
0.36\end{array}$ \\
\hline Africa mean ${ }^{7}$ & $\begin{array}{r}0.11- \\
0.17\end{array}$ & $17-30$ & $0.058-0.43$ & $0.4-0.533$ & $\begin{array}{c}0.0026- \\
0.016\end{array}$ & $0.63-1.397$ & $0.44-29.72$ & $0.35-5.04$ & - & $\begin{array}{r}0.89- \\
3.12\end{array}$ \\
\hline Europe mean ${ }^{7}$ & $\begin{array}{r}0.21- \\
2.21\end{array}$ & $0.02-0.42$ & $0.084-0.26$ & $\begin{array}{r}<0.85- \\
11.46\end{array}$ & 0.01 & $0.456-3.53$ & $3.76-48$ & $0.92-5.06$ & - & $4.98-27$ \\
\hline $\begin{array}{l}\text { North America } \\
\text { mean }^{7}\end{array}$ & $\begin{array}{r}0.12- \\
0.91\end{array}$ & $0.014-0.18$ & 0.02 & $0.241-2.1$ & $\begin{array}{r}0.0006- \\
0.0070\end{array}$ & $\begin{array}{r}0.841- \\
1.930\end{array}$ & $0.41-14.86$ & $\begin{array}{l}0.47- \\
10.39\end{array}$ & - & $\begin{array}{r}0.12- \\
3.79\end{array}$ \\
\hline $\begin{array}{l}\text { South America } \\
\text { mean }^{7}\end{array}$ & - & 0.17 & $\begin{array}{r}0.017- \\
0.766\end{array}$ & 0.72 & $0.006-0.013$ & $\begin{array}{r}0.227- \\
1.997\end{array}$ & $\begin{array}{l}0.46- \\
113.52\end{array}$ & $0.21-0.92$ & - & $\begin{array}{c}0.27- \\
3.1\end{array}$ \\
\hline
\end{tabular}

1: [9]; 2: [9]; 3, 4: [21]; 5: [47]; 6: [39]; 7:[12]

In the Rupa Lake, four PCs with eigenvalues $>1$ explained about $85.71 \%$ of the total variance. PC1 accounts for $34.31 \%$ of the total variance, which had strong positive loadings on $\mathrm{Co}, \mathrm{Cr}, \mathrm{Mn}$, and $\mathrm{Pb}$ and moderate positive loadings on As. PC2, which explained $28.98 \%$ of the total variance, had strong positive loadings on $\mathrm{Cu}, \mathrm{Ni}$, and $\mathrm{Zn}$. Similarly, PC3 explained $12.31 \%$ of the total variance, and also had strong loadings on Cs. And, PC4 explained about $10.11 \%$ of the total variance with strong loading on $\mathrm{Cd}$. The co-locations of the PC1, $P C 2$, and $P C 3$ indicated that they are primarily associated with natural weathering and transportation of the materials. The PC4 specified their common sources and is likely to be influenced by agricultural activities that could be deduced to the mixed sources including lithogenic and anthropic.

The correlation coefficient of Rupa Lake is illustrated in Table 4. A strong correlation indicates similar sources such as weathering and transport processes [12], agriculture runoff, untreated municipal, and industrial wastes [4]. In the study, Zn was strongly correlated with
$\mathrm{Ni}(p<0.01)$ indicating that $\mathrm{Zn}$ and $\mathrm{Ni}$ were also contributed from anthropic sources. Similarly, $\mathrm{Mn}-\mathrm{Co} ; \mathrm{Pb}-\mathrm{As}$; $\mathrm{Pb}-\mathrm{Cu} ; \mathrm{Zn}-\mathrm{Cs}$; and $\mathrm{Zn}$-Cu pairs were moderately correlated with each other $(p<0.05)$ showing their more than one sources.

PCA results attributed the major geogenic contributions with minor anthropic signatures in both the lakes, and the results are in good agreement with correlation analysis in both the lakes.

\subsection{Water quality index (WQI)}

WQI of Begnas Lake and Rupa Lake is presented in Table 5. According to $\mathrm{WHO}$, the $\mathrm{Cd}, \mathrm{Cr}, \mathrm{Pb}$, and $\mathrm{Mn}$ are given the maximum weightage due to their high toxicity to public health. The health impact of such metals is peripheral neuropathy, carcinogenicity (skin, lung, and bladder cancer), tubular neurodevelopment, cardiovascular diseases, adverse pregnancy, hypertension, and infertility [38]. The WQI of the lakes was found to be 2.67 and 5.66, respectively, as in Table 5. Based on the WQI values $(\mathrm{WQI}<50)$, 


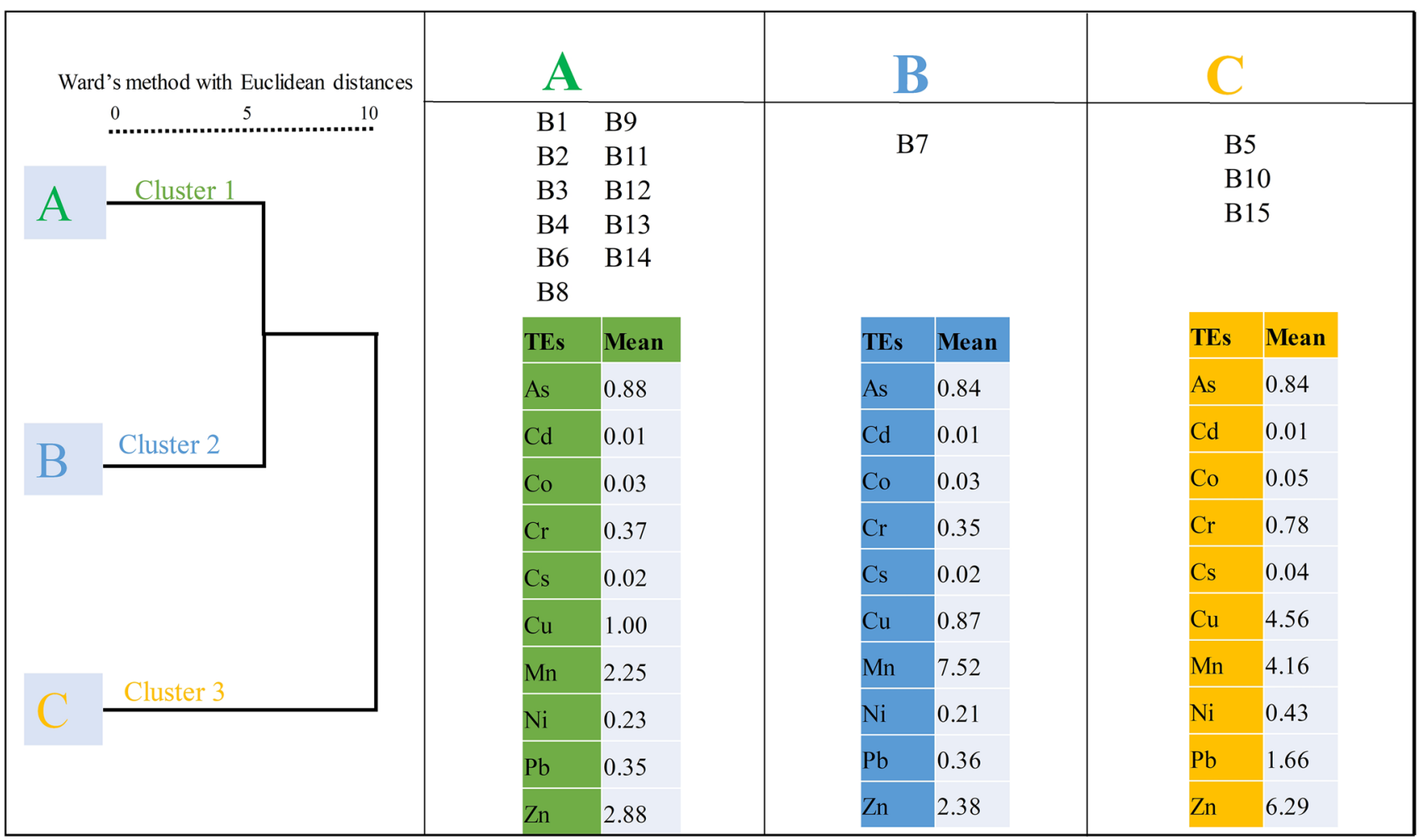

Fig. 3 Clustering of water samples in dendrogram from the Begnas Lake, Gandaki Province, Nepal (concentration of the TEs are expressed in $\mu \mathrm{g} / \mathrm{L})$

Fig. 4 Clustering of water samples in dendrogram from the Rupa Lake, Gandaki Province, Nepal (concentration of the TEs are expressed in $\mu \mathrm{g} / \mathrm{L}$ )

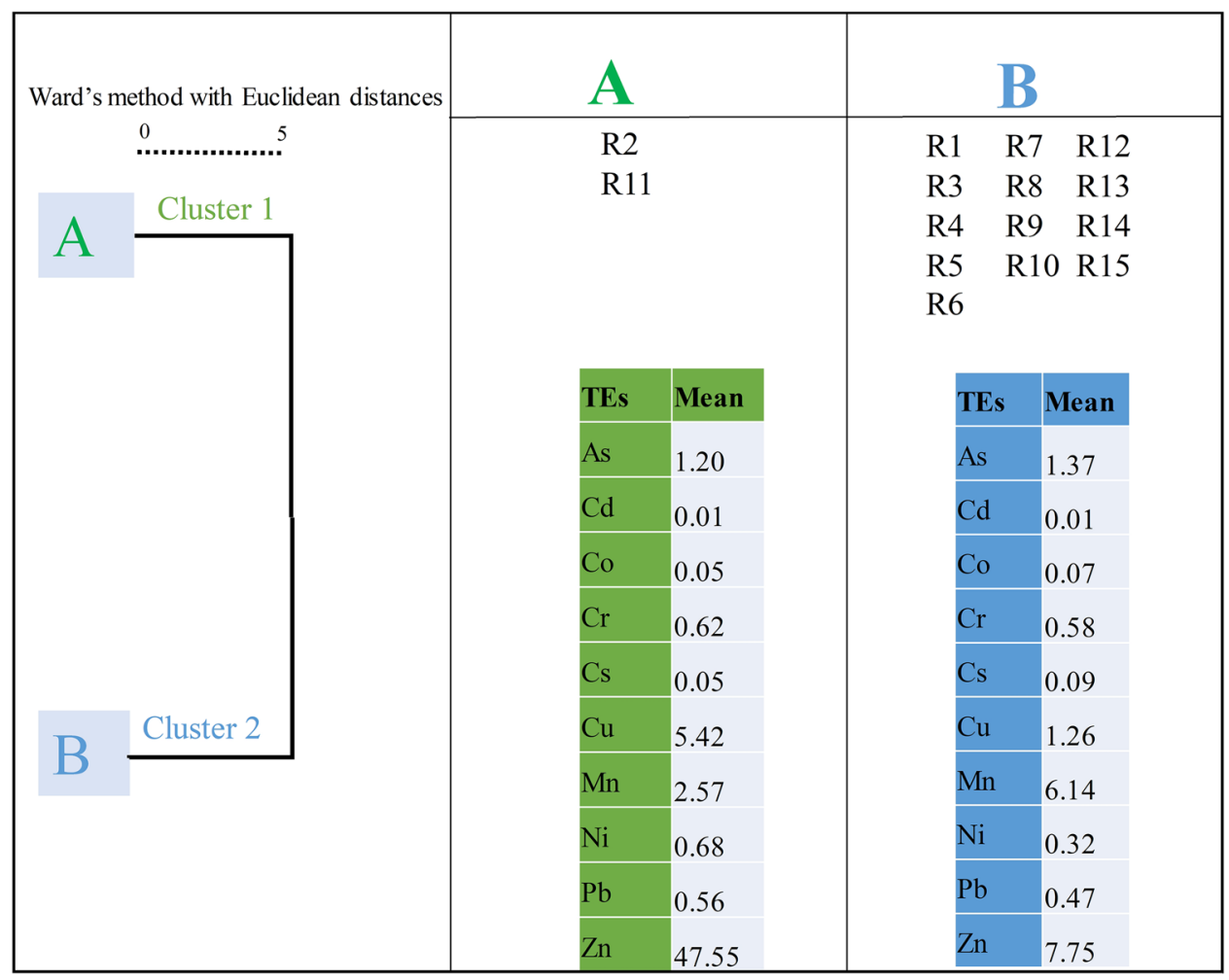


(A)

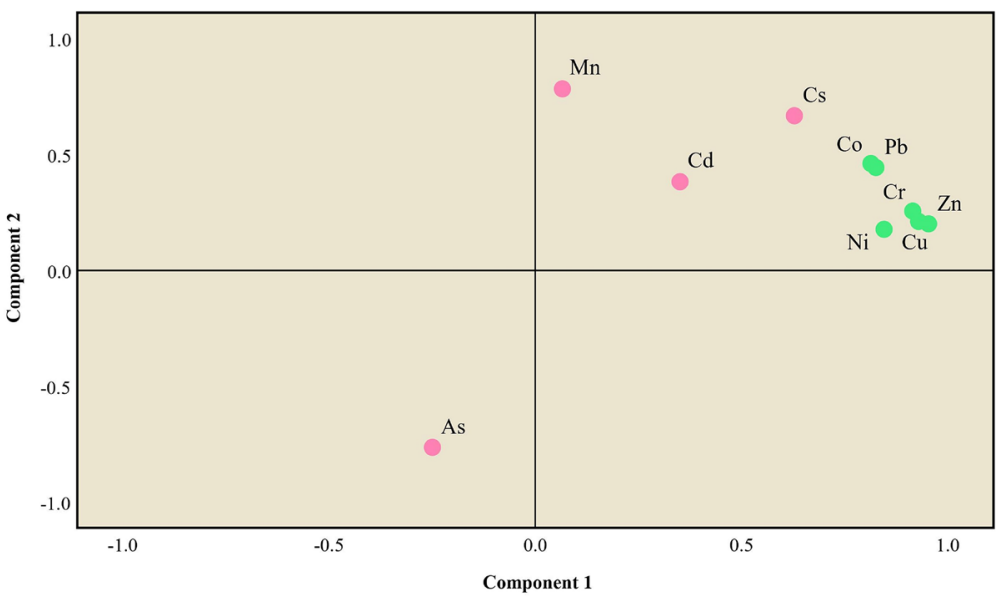

(B)

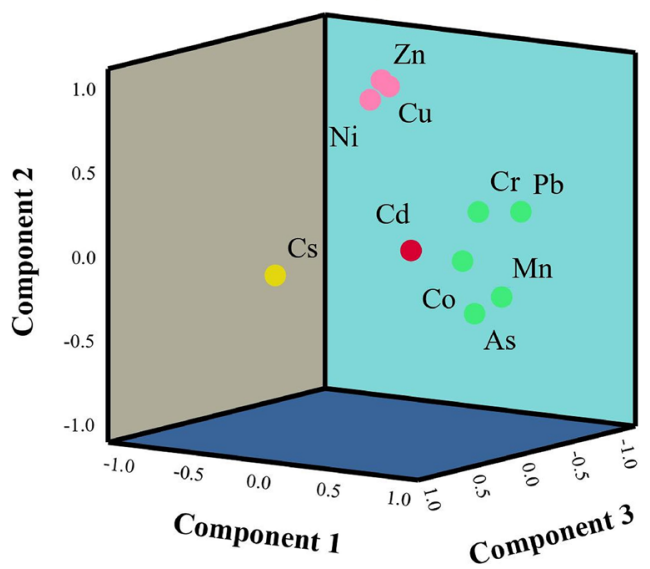

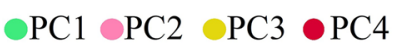

Fig. 5 Factor loading plots of principal component analysis (PCA) of trace elements (TEs), a Begnas Lake and b Rupa Lake, Gandaki Province, Nepal

Table 3 Factor loadings table of principal component analysis (PCA) of Begnas and Rupa Lake, Gandaki Province, Nepal

\begin{tabular}{|c|c|c|c|c|c|c|}
\hline \multirow[t]{2}{*}{ Variables } & \multirow{2}{*}{$\frac{\text { Begnas Lake }}{\text { PC } 1}$} & \multirow[b]{2}{*}{ PC 2} & \multicolumn{4}{|c|}{ Rupa Lake } \\
\hline & & & PC 1 & PC 2 & PC 3 & PC 4 \\
\hline As & -0.25 & -0.76 & 0.62 & -0.36 & -0.17 & -0.41 \\
\hline $\mathrm{Cd}$ & 0.35 & 0.38 & 0.13 & -0.03 & -0.21 & 0.86 \\
\hline Co & 0.81 & 0.46 & 0.79 & 0.03 & 0.19 & 0.30 \\
\hline $\mathrm{Cr}$ & 0.92 & 0.26 & 0.79 & 0.30 & 0.03 & 0.01 \\
\hline Cs & 0.63 & 0.67 & -0.04 & -0.04 & 0.93 & -0.18 \\
\hline $\mathrm{Cu}$ & 0.93 & 0.21 & -0.01 & 0.93 & -0.20 & -0.13 \\
\hline $\mathrm{Mn}$ & 0.07 & 0.78 & 0.91 & -0.21 & -0.04 & 0.22 \\
\hline $\mathrm{Ni}$ & 0.85 & 0.18 & 0.15 & 0.93 & 0.23 & 0.12 \\
\hline $\mathrm{Pb}$ & 0.83 & 0.44 & 0.87 & 0.26 & -0.28 & -0.18 \\
\hline $\mathrm{Zn}$ & 0.95 & 0.20 & 0.02 & 0.99 & -0.07 & 0.02 \\
\hline Eigenvalues & 6.54 & 1.10 & 3.43 & 2.90 & 1.23 & 1.01 \\
\hline Variance (\%) & 65.36 & 10.96 & 34.31 & 28.98 & 12.31 & 10.11 \\
\hline Cumulative (\%) & 65.36 & 76.32 & 34.31 & 63.29 & 75.60 & 85.71 \\
\hline
\end{tabular}

the water quality of both the lakes was excellent and acceptable for drinking purposes. The results are also in good agreement with previous studies of the same area $[4,9]$.

\subsection{Metal index (MI)}

If the Ml of the lake water is $>1$, it is unacceptable for drinking purposes [9]. The MI value of the water in Begnas Lake and Rupa Lake was 0.45 and 1.39, respectively (Table 5 and Fig. 6). The findings showed that the Begnas Lake was relatively safe for drinking and household applications, whereas the Rupa Lake did not comply with the MI guidelines precisely for $\mathrm{Zn}(\mathrm{MI}=1.30)$. It indicates that the elevated concentration of $\mathrm{Zn}$ in in the Rupa Lake could have adverse impacts on its portability. Prior literature from the Phewa Lake suggested that the MI index for $\mathrm{Zn}, \mathrm{Mn}$, and As was estimated to be 3.36 [9], suggesting that the TEs have elevated concentrations in the freshwater lakes of Pokhara Valley, Nepal. 
Table 4 Correlation matrix of TTEs in Begnas Lake and Rupa Lake

\begin{tabular}{|c|c|c|c|c|c|c|c|c|c|c|}
\hline Variables & As & $\mathrm{Cd}$ & Co & $\mathrm{Cr}$ & Cs & $\mathrm{Cu}$ & $\mathrm{Mn}$ & $\mathrm{Ni}$ & $\mathrm{Pb}$ & $\mathrm{Zn}$ \\
\hline \multicolumn{11}{|c|}{ Begnas Lake } \\
\hline As & 1.00 & & & & & & & & & \\
\hline $\mathrm{Cd}$ & -0.19 & 1.00 & & & & & & & & \\
\hline Co & -0.28 & 0.42 & 1.00 & & & & & & & \\
\hline $\mathrm{Cr}$ & -0.11 & -0.02 & $0.58^{*}$ & 1.00 & & & & & & \\
\hline Cs & -0.29 & 0.39 & 0.22 & 0.16 & 1.00 & & & & & \\
\hline $\mathrm{Cu}$ & -0.13 & 0.29 & $0.54^{*}$ & $0.67^{* *}$ & 0.46 & 1.00 & & & & \\
\hline $\mathrm{Mn}$ & -0.44 & 0.15 & $0.60^{*}$ & 0.46 & 0.17 & 0.09 & 1.00 & & & \\
\hline $\mathrm{Ni}$ & -0.25 & 0.38 & $0.59^{*}$ & $0.76^{* *}$ & 0.21 & $0.84^{* *}$ & 0.31 & 1.00 & & \\
\hline $\mathrm{Pb}$ & -0.44 & 0.07 & 0.41 & $0.66^{* *}$ & 0.07 & $0.67^{* *}$ & 0.28 & $0.74^{* *}$ & 1.00 & \\
\hline $\mathrm{Zn}$ & -0.21 & 0.28 & 0.44 & $0.70^{* *}$ & 0.46 & $0.90^{* *}$ & 0.07 & $0.85^{* *}$ & $0.64^{* *}$ & 1.00 \\
\hline \multicolumn{11}{|c|}{ Rupa Lake } \\
\hline As & 1.00 & & & & & & & & & \\
\hline $\mathrm{Cd}$ & 0.37 & 1.00 & & & & & & & & \\
\hline Co & 0.30 & 0.50 & 1.00 & & & & & & & \\
\hline $\mathrm{Cr}$ & -0.18 & -0.09 & 0.36 & 1.00 & & & & & & \\
\hline Cs & 0.33 & 0.20 & 0.30 & 0.11 & 1.00 & & & & & \\
\hline $\mathrm{Cu}$ & 0.21 & 0.19 & 0.08 & 0.11 & 0.11 & 1.00 & & & & \\
\hline $\mathrm{Mn}$ & 0.43 & 0.35 & $0.54^{*}$ & 0.33 & 0.12 & -0.03 & 1.00 & & & \\
\hline $\mathrm{Ni}$ & -0.37 & 0.19 & 0.20 & 0.26 & 0.42 & 0.33 & -0.31 & 1.00 & & \\
\hline $\mathrm{Pb}$ & $0.65^{* *}$ & 0.50 & 0.33 & 0.24 & 0.21 & $0.72^{* *}$ & 0.43 & 0.07 & 1.00 & \\
\hline $\mathrm{Zn}$ & -0.08 & 0.18 & 0.22 & 0.41 & $0.52^{*}$ & $0.61^{*}$ & -0.20 & $0.82^{* *}$ & 0.38 & 1.00 \\
\hline
\end{tabular}

\subsection{Health risk assessment (HRA)}

The HRA is the tool for assessing the potential public health risk posed by TEs. The hazard index $(\mathrm{HI})$ and hazard quotient (HQ) for $\mathrm{As}, \mathrm{Cd}, \mathrm{Co}, \mathrm{Cr}, \mathrm{Cu}, \mathrm{Mn}, \mathrm{Ni}, \mathrm{Pb}$, and $\mathrm{Zn}$ were

Table 5 Water quality index (WQI) and metal index (MI) of the Begnas Lake and Rupa Lake, Gandaki Province, Nepal

\begin{tabular}{llllll}
\hline TEs & WQI & & & MI \\
\cline { 2 - 3 } \cline { 5 - 6 } & Begnas Lake & Rupa Lake & & Begnas Lake & Rupa Lake \\
\hline $\mathrm{Cd}$ & 0.057 & 0.06 & & 0.003 & 0.003 \\
$\mathrm{Cr}$ & 0.155 & 0.2 & & 0.009 & 0.012 \\
$\mathrm{Cu}$ & 0.059 & 0.06 & & 0.009 & 0.009 \\
$\mathrm{~Pb}$ & 1.052 & 0.71 & & 0.061 & 0.041 \\
$\mathrm{Mn}$ & 0.103 & 0.05 & & 0.007 & 0.014 \\
$\mathrm{As}$ & 0.005 & 0.01 & & 0 & 0 \\
$\mathrm{Zn}$ & 1.217 & 4.5 & & 0.353 & 1.306 \\
$\mathrm{Co}$ & 0.003 & 0 & & 0.001 & 0.001 \\
$\mathrm{Ni}$ & 0.013 & 0.07 & & 0.004 & 0.005 \\
Total & 2.66 & 5.66 & 0.45 & 1.392 \\
\hline
\end{tabular}

analyzed (Table 6). The results of Begnas Lake revealed that $\mathrm{As}, \mathrm{Cd}, \mathrm{Cr}, \mathrm{Mn}, \mathrm{Co}, \mathrm{Pb}$, and $\mathrm{Cu}$ were relatively high contributors of $\mathrm{HI}$, where As and $\mathrm{Pb}$ could be the chronic exposures to inhabitants in terms of ingestion (Table 6). Moreover, $\mathrm{As}, \mathrm{Cd}, \mathrm{Cr}$, and $\mathrm{Mn}$ were relatively high contributors to the inhabitants via the dermal path. In the case of Rupa Lake, $\mathrm{As}, \mathrm{Cd}, \mathrm{Co}, \mathrm{Cr}, \mathrm{Cu}, \mathrm{Mn}, \mathrm{Pb}$, and $\mathrm{Zn}$ (except $\mathrm{Ni}$ ) were relatively high contributors in terms of $\mathrm{HI}$, where $\mathrm{As}, \mathrm{Co}, \mathrm{Cr}, \mathrm{Cu}, \mathrm{Mn}$, $\mathrm{Pb}$, and $\mathrm{Zn}$ could be the chronic exposures to inhabitants in terms of ingestion (Table 6). Also, As, $\mathrm{Cd}, \mathrm{Cr}$, and $\mathrm{Mn}$ were found relatively high contributors to the inhabitants via the dermal path in the Rupa Lake. In both the lakes, the $\mathrm{HI}$ and $\mathrm{HQ}$ values were $<1$ signifying that there are minimal adverse impacts to the public from the consumptions of lake waters.

\subsection{Cancer risk (CR)}

The TEs such as $\mathrm{As}, \mathrm{Cd}, \mathrm{Cr}$, and $\mathrm{Pb}$ are considered as the carcinogenic elements [43]. The CR depends on age with exposure condition and duration of exposure to the carcinogenic elements [23]. These factors should be 


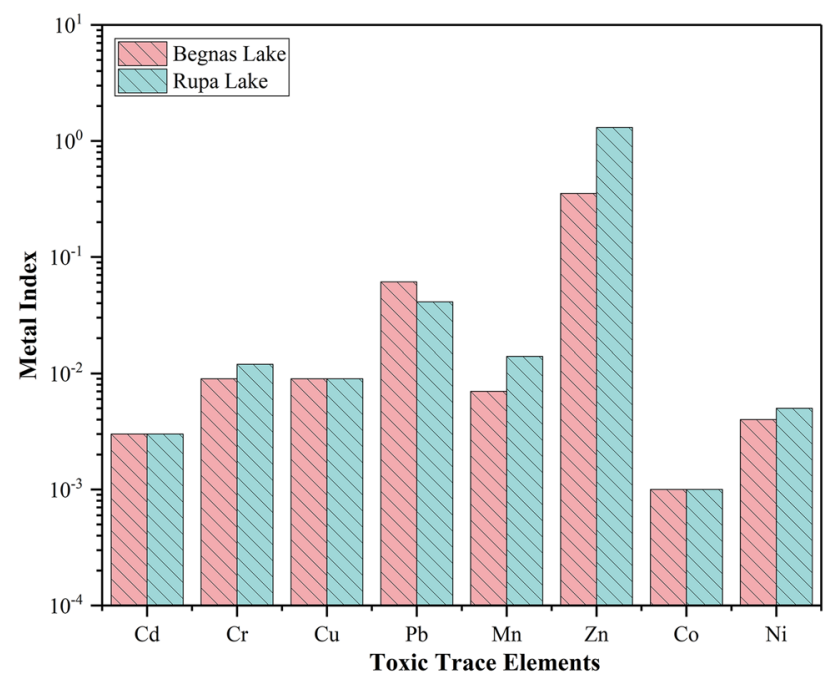

Fig. 6 Metal index of trace elements (TEs) for the Begnas Lake and Rupa Lake, Gandaki Province, Nepal

considered while assessing the $C R$. The $C R$ assessment of the TEs has been presented in Table 7. The acceptable range of CR by the US EPA is $10^{-6}$ to $10^{-4}$. Thus, the result showed the $\mathrm{CR}<1 \times 10^{-4}$ in both Rupa Lake and Begnas Lake, indicating the level of TEs within the tolerance limit. In addition, these results demonstrated that the $C R$ was comparable in both the study lakes. However,
Table 6 Health risk assessment (HRA) of Begnas Lake and Rupa Lake, Gandaki Province, Nepal

\begin{tabular}{|c|c|c|c|c|}
\hline TEs & $\mathrm{Cw}$ & $\mathrm{HQ}$ ing & HQ derm & $\mathrm{HI}$ \\
\hline \multicolumn{5}{|c|}{ Begnas lake } \\
\hline As & 0.87 & $1.19 \times 10^{-1}$ & $2.98 \times 10^{-3}$ & $1.22 \times 10^{-1}$ \\
\hline $\mathrm{Cd}$ & 0.01 & $8.18 \times 10^{-4}$ & $8.44 \times 10^{-3}$ & $9.26 \times 10^{-3}$ \\
\hline Co & 0.03 & $4.09 \times 10^{-3}$ & $8.44 \times 10^{-5}$ & $4.18 \times 10^{-3}$ \\
\hline $\mathrm{Cr}$ & 0.45 & $6.14 \times 10^{-3}$ & $1.27 \times 10^{-2}$ & $1.88 \times 10^{-2}$ \\
\hline $\mathrm{Cu}$ & 1.7 & $1.74 \times 10^{-3}$ & $5.98 \times 10^{-5}$ & $1.80 \times 10^{-3}$ \\
\hline $\mathrm{Mn}$ & 2.98 & $6.10 \times 10^{-3}$ & $1.57 \times 10^{-3}$ & $7.67 \times 10^{-3}$ \\
\hline $\mathrm{Ni}$ & 0.27 & $5.52 \times 10^{-4}$ & $4.22 \times 10^{-6}$ & $5.57 \times 10^{-4}$ \\
\hline $\mathrm{Pb}$ & 0.61 & $1.78 \times 10^{-2}$ & $6.13 \times 10^{-5}$ & $1.79 \times 10^{-2}$ \\
\hline $\mathrm{Zn}$ & 3.53 & $4.81 \times 10^{-4}$ & $1.49 \times 10^{-5}$ & $4.96 \times 10^{-4}$ \\
\hline \multicolumn{5}{|c|}{ Rupa lake } \\
\hline As & 1.34 & $1.83 \times 10^{-1}$ & $4.60 \times 10^{-3}$ & $1.87 \times 10^{-1}$ \\
\hline $\mathrm{Cd}$ & 0.01 & $8.18 \times 10^{-4}$ & $8.44 \times 10^{-3}$ & $9.26 \times 10^{-3}$ \\
\hline Co & 0.06 & $8.18 \times 10^{-3}$ & $1.69 \times 10^{-4}$ & $8.35 \times 10^{-3}$ \\
\hline $\mathrm{Cr}$ & 0.58 & $7.91 \times 10^{-3}$ & $1.63 \times 10^{-2}$ & $2.42 \times 10^{-2}$ \\
\hline $\mathrm{Cu}$ & 1.81 & $1.85 \times 10^{-3}$ & $6.36 \times 10^{-5}$ & $1.91 \times 10^{-3}$ \\
\hline $\mathrm{Mn}$ & 5.67 & $1.16 \times 10^{-2}$ & $2.99 \times 10^{-3}$ & $1.46 \times 10^{-2}$ \\
\hline $\mathrm{Ni}$ & 0.37 & $7.57 \times 10^{-4}$ & $5.78 \times 10^{-6}$ & $7.63 \times 10^{-4}$ \\
\hline $\mathrm{Pb}$ & 0.48 & $1.40 \times 10^{-2}$ & $4.82 \times 10^{-5}$ & $1.41 \times 10^{-2}$ \\
\hline $\mathrm{Zn}$ & 13.06 & $1.78 \times 10^{-3}$ & $5.51 \times 10^{-5}$ & $1.84 \times 10^{-3}$ \\
\hline
\end{tabular}

it was lower than the previous study conducted in the same region indicating the better water quality in this study (9) Table 7.
Table 7 Cancer risk assessment of the trace elements (TEs) of Begnas Lake and Rupa Lake, Gandaki Province, Nepal

\begin{tabular}{|c|c|c|c|c|c|c|}
\hline TEs & $\mathrm{Cw}$ & $\mathrm{Cr}_{\text {ing }}$ & $\mathrm{Cr}_{\text {der }}$ & $\mathrm{Cl}$ & CR level & CR category \\
\hline \multicolumn{7}{|c|}{ Begnas lake } \\
\hline As & 0.87 & $2.37 \times 10^{-5}$ & $2.45 \times 10^{-7}$ & $2.40 \times 10^{-5}$ & $<1.00 \times 10^{-3}$ & Very Low \\
\hline $\mathrm{Cd}$ & 0.01 & $2.73 \times 10^{-7}$ & $2.81 \times 10^{-9}$ & $2.76 \times 10^{-7}$ & $<1.00 \times 10^{-3}$ & Very Low \\
\hline $\mathrm{Cr}$ & 0.45 & $1.23 \times 10^{-5}$ & $1.27 \times 10^{-7}$ & $1.24 \times 10^{-5}$ & $<1.00 \times 10^{-3}$ & Very Low \\
\hline $\mathrm{Pb}$ & 0.61 & $1.66 \times 10^{-5}$ & $1.72 \times 10^{-8}$ & $1.67 \times 10^{-5}$ & $<1.00 \times 10^{-3}$ & Very Low \\
\hline $\mathrm{Zn}$ & 3.53 & $9.63 \times 10^{-5}$ & $5.96 \times 10^{-7}$ & $9.69 \times 10^{-5}$ & $<1.00 \times 10^{-3}$ & Very Low \\
\hline \multicolumn{7}{|c|}{ Rupa lake } \\
\hline As & 1.34 & $3.65 \times 10^{-5}$ & $3.77 \times 10^{-7}$ & $3.69 \times 10^{-5}$ & $<1.00 \times 10^{-3}$ & Very Low \\
\hline $\mathrm{Cd}$ & 0.01 & $2.73 \times 10^{-7}$ & $2.81 \times 10^{-9}$ & $2.76 \times 10^{-7}$ & $<1.00 \times 10^{-3}$ & Very Low \\
\hline $\mathrm{Cr}$ & 0.58 & $1.58 \times 10^{-5}$ & $1.63 \times 10^{-7}$ & $1.60 \times 10^{-5}$ & $<1.00 \times 10^{-3}$ & Very Low \\
\hline $\mathrm{Pb}$ & 0.48 & $1.31 \times 10^{-5}$ & $1.35 \times 10^{-8}$ & $1.31 \times 10^{-5}$ & $<1.00 \times 10^{-3}$ & Very Low \\
\hline $\mathrm{Zn}$ & 13.06 & $3.56 \times 10^{-4}$ & $2.20 \times 10^{-6}$ & $3.58 \times 10^{-4}$ & $<1.00 \times 10^{-3}$ & Very Low \\
\hline
\end{tabular}




\section{Conclusion}

This study was undertaken to evaluate the sources, distributions, and potential health risks of trace elements (TEs) in Begnas Lake and Rupa Lake, Gandaki Province, Nepal. In the Rupa Lake, the average concentration of the TEs was in the dominance order of $\mathrm{Zn}>\mathrm{Mn}>\mathrm{Cu}>$ $\mathrm{As}>\mathrm{Cr}>\mathrm{Pb}>\mathrm{Ni}>\mathrm{Cs}>\mathrm{Co}>\mathrm{Cd}$, whereas in the Begnas Lake, the order of concentrations was $\mathrm{Zn}>\mathrm{Mn}>\mathrm{Cu}>\mathrm{As}$ $>\mathrm{Pb}>\mathrm{Cr}>\mathrm{Ni}>\mathrm{Co}>\mathrm{Cs}>\mathrm{Cd}$. The two and four principal components were observed in the Begnas Lake and Rupa Lake, respectively, signifying the geogenic contributions with minor anthropic signatures of TEs in both the lakes. The PCA results conclude that the elevated concentrations of $\mathrm{Cr}, \mathrm{Cu}, \mathrm{Mn}, \mathrm{Pb}$, and $\mathrm{Zn}$ were contributed from both geogenic and anthropic sources.

Based on the water quality index, both the lakes were safe and acceptable for drinking purposes. However, the metal index in Rupa Lake in terms of $\mathrm{Zn}$ may pose adverse impacts to the consumers. The hazard index and hazard quotient signify that there were minimum adverse impacts to the public from the consumptions of lake waters. Also, the cancer risk of the TEs indicates that both the Begnas Lake and Rupa Lake have low risk $\left(\mathrm{Cl}<1 \times 10^{-4}\right)$. Overall, the water quality of both the lakes was found to be good, but more prevention and control measures should be taken to keep water resources safer for the protection of human health and the aquatic ecosystem. Finally, this study should be a baseline for the distribution and risk appraisal of TEs in the lakes; however, seasonality impacts with depth-wise investigations are recommended for the further studies.

Acknowledgements We would like to thank Prof. Dr. Zhang Fan, Institute of Tibetan Plateau Research, Chinese Academy of Sciences, China; and Prof. Dr. Madan Koirala, Prof. Dr. Kedar Rijal, and Prof. Dr. Rejina Maskey of Central Department of Environmental Science, Tribhuvan University, Nepal, for their institutional and moral supports. In addition, we would like to thank Dr. Subash Adhikari and Mr. Ramesh Basnet for their supports during the sample collection.

Author contributions RRP contributed to conceptualization and data collection; RRP, LK, BBB, and KBP contributed to writing of the original manuscript; KB, LK contributed to preparation of figures and/ or tables; LBT, YPD, B.R.P., and YRB contributed to review and editing. All authors have approved the final version of the manuscript.

Funding This research received no external funding.

\section{Declarations}

Conflict of interest The author(s) declare that they have no conflict of interest.

Open Access This article is licensed under a Creative Commons Attribution 4.0 International License, which permits use, sharing, adaptation, distribution and reproduction in any medium or format, as long as you give appropriate credit to the original author(s) and the source, provide a link to the Creative Commons licence, and indicate if changes were made. The images or other third party material in this article are included in the article's Creative Commons licence, unless indicated otherwise in a credit line to the material. If material is not included in the article's Creative Commons licence and your intended use is not permitted by statutory regulation or exceeds the permitted use, you will need to obtain permission directly from the copyright holder. To view a copy of this licence, visit http://creativecommons.org/licenses/by/4.0/.

\section{References}

1. Xiao J, Jin Z, Wang J (2014) Geochemistry of trace elements and water quality assessment of natural water within the Tarim River Basin in the extreme arid region, NW China. J Geochemical Explor 136:118-126. https://doi.org/10.1016/j.gexplo.2013.10.013

2. Pant RR et al (2019) Water quality assessment of Begnas and Rupa Lakes, Lesser Himalaya Pokhara, Nepal. J Inst Eng 15(2):113-122. https://doi.org/10.3126/jie.v15i2.27655

3. Pant RR, Adhikari NL (2015) Water quality assessment of Phewa Lake, Pokhara Nepal. Cogn Transdiscipl Res J 1:130-140

4. Sharma CM et al (2015) Mercury and selected trace elements from a remote (gosainkunda) and an urban (Phewa) Lake Waters of Nepal. Water Air Soil Pollut. https://doi.org/10.1007/ s11270-014-2276-3

5. Singh VB, Ramanathan AL, Mandal A (2016) Hydrogeochemistry of high-altitude lake: a case study of the Chandra Tal, Western Himalaya, India. Arab J Geosci 9(4):1-9. https://doi.org/10.1007/ s12517-016-2358-1

6. Shah MT, Ara J, Muhammad S, Khan S, Tariq S (2012) Health risk assessment via surface water and sub-surface water consumption in the mafic and ultramafic terrain, Mohmand agency, northern Pakistan. J Geochemical Explor 118:60-67. https://doi.org/10. 1016/j.gexplo.2012.04.008

7. Sun X et al (2020) Mercury variation and export in trans-Himalayan rivers: Insights from field observations in the Koshi River. Sci Total Environ. https://doi.org/10.1016/j.scitotenv.2020.139836

8. Li S, Zhang Q (2010) Risk assessment and seasonal variations of dissolved trace elements and heavy metals in the Upper Han River, China. J Hazard Mater 181:1051-1058. https://doi.org/10. 1016/j.jhazmat.2010.05.120

9. Rupakheti D, Tripathee L, Kang S, Sharma CM, Paudyal R, Sillanpää M (2017) Assessment of water quality and health risks for toxic trace elements in urban Phewa and remote Gosainkunda lakes, Nepal. Hum Ecol Risk Assess 23(5):959-973. https://doi.org/10. 1080/10807039.2017.1292117

10. Peng F, Xie F, Muzik O (2018) Alteration of copper fluxes in brain aging: a longitudinal study in Rodent using 64CuCl2-PET/CT. Aging Dis 9(1):109-118. https://doi.org/10.14336/AD.2017.1025

11. Mochizuki A et al (2018) Distribution of trace elements and the influence of major-ion water chemistry in saline lakes. Limnol Oceanogr 63(3):1253-1263. https://doi.org/10.1002/Ino.10770

12. J Gaillardet, J Viers, and B Dupré, 2014 Trace Elements in River Waters. In:Treatise on Geochemistry. Elsevier, New York

13. Li X et al (2016) Diurnal dynamics of minor and trace elements in stream water draining Dongkemadi Glacier on the Tibetan Plateau and its environmental implications. J Hydrol 541:1104-1118. https://doi.org/10.1016/j.jhydrol.2016.08.021

14. Pu T et al (2020) New insights into trace elements in the water cycle of a karst-dominated glacierized region, southeast Tibetan 
Plateau. Sci Total Environ. https://doi.org/10.1016/j.scitotenv. 2020.141725

15. B Qu, R Paudyal, RR Pant, and FUR Qaiser 2020 Inorganic components in river waters in the Third Pole

16. Zhang Y, Sillanpää M, Li C, Guo J, Qu B, Kang S (2015) River water quality across the Himalayan regions: elemental concentrations in headwaters of Yarlung Tsangbo, Indus and Ganges River. Environ Earth Sci 73(8):4151-4163. https://doi.org/10.1007/ s12665-014-3702-y

17. Qu B, Zhang Y, Kang S, Sillanpää M (2019) Water quality in the Tibetan Plateau: Major ions and trace elements in rivers of the 'Water Tower of Asia.' Sci Total Environ 649:571-581. https://doi. org/10.1016/j.scitotenv.2018.08.316

18. Huang $X$, Sillanpää $M$, Gjessing ET, Vogt RD (2009) Water quality in the Tibetan Plateau: Major ions and trace elements in the headwaters of four major Asian rivers. Sci Total Environ 407(24):62426254. https://doi.org/10.1016/j.scitotenv.2009.09.001

19. Chakrapani GJ (2005) Major and trace element geochemistry in upper Ganga river in the Himalayas, India. Environ Geol 48(2):189-201. https://doi.org/10.1007/s00254-005-1287-1

20. Jin Z, You CF, Yu TL, Wang BS (2010) Sources and flux of trace elements in river water collected from the Lake Qinghai catchment, NE Tibetan Plateau. Appl Geochemistry 25(10):1536-1546. https://doi.org/10.1016/j.apgeochem.2010.08.004

21. Paudyal $R$ et al (2016) Major ions and trace elements of two selected rivers near Everest region, southern Himalayas, Nepal. Environ Earth Sci 75(1):1-11. https://doi.org/10.1007/ s12665-015-4811-y

22. Pant RR, Zhang F, Rehman FU, Koirala M, Rijal K, Maskey R (2020) Spatiotemporal characterization of dissolved trace elements in the Gandaki River, Central Himalaya Nepal. J Hazard Mater. https://doi.org/10.1016/j.jhazmat.2019.121913

23. Tripathee $L$ et al (2016) Preliminary health risk assessment of potentially toxic metals in surface water of the himalayan rivers, Nepal. Bull Environ Contam Toxicol 97(6):855-862. https://doi. org/10.1007/s00128-016-1945-x

24. Pant RR et al (2019) Water quality assessment of the Betkot Lake, Sudurpaschim Province, Nepal. North Am Acad Res. https://doi. org/10.5281/zenodo.3566682

25. KB Pal, RR Pant, B Rimal, AD Mishar, and AD Pal, KB Pant, RR Rimal, B Mishra 2019 Comparative Assessment of Water Quality in the Bagmati River Basin. Nepal, 5, 68-78,

26. K Oli, 1996 Environmental study of Nepal's Begnas and Rupa Lakes. 152

27. Khadka UR, Ramanathan AL (2013) Major ion composition and seasonal variation in the Lesser Himalayan lake: case of Begnas Lake of the Pokhara Valley, Nepal. Arab J Geosci 6(11):4191-4206. https://doi.org/10.1007/s12517-012-0677-4

28. Dhital MR (2015) Geology of the Nepal Himalaya: regional perspective of the classic collided orogen. Springer. https://doi.org/ 10.3126/ije.v3i2.10502

29. U Khadka and A Ramanathan 2013 Depthwise variation of carbon , nitrogen and biogenic silica in sediment from Depthwise variation of carbon, nitrogen and biogenic silica in sediment from lakes of Pokhara Valley, Nepal. Nepal J Environ Sci 1

30. Regmi RR, Saha SK, Subedi DS (2017) Geospatial analysis of land use land cover change modeling in Phewa Lake watershed of nepal by using GEOMOD model. Himal Phys 6:65-72. https://doi. org/10.3126/hj.v6i0.18363

31. Wang G, Zeng C, Zhang F, Zhang Y, Scott CA, Yan X (2017) Trafficrelated trace elements in soils along six highway segments on the Tibetan Plateau: influence factors and spatial variation. Sci Total Environ. https://doi.org/10.1016/j.scitotenv.2017.01.018

32. Varol M, Gökot B, Bekleyen A (2013) Dissolved heavy metals in the Tigris River (Turkey): spatial and temporal variations.
Environ Sci Pollut Res 20(9):6096-6108. https://doi.org/10.1007/ s11356-013-1627-8

33. Rehman Qaisar FU, Zhang F, Pant RR, Wang G, Khan S, Zeng C (2018) Spatial variation, source identification, and quality assessment of surface water geochemical composition in the Indus River Basin, Pakistan. Environ Sci Pollut Res. https://doi.org/10. 1007/s11356-018-1519-z

34. Zhang F et al (2019) Meltwater hydrochemistry at four glacial catchments in the headwater of Indus River. Environ Sci Pollut Res 26:23645-23660. https://doi.org/10.1007/s11356-019-05422-5

35. Pant RR et al (2018) Spatiotemporal variations of hydrogeochemistry and its controlling factors in the Gandaki River Basin, Central Himalaya Nepal. Sci Total Environ. https://doi.org/10.1016/j.scito tenv.2017.12.063

36. Meng Q, Zhang J, Zhang Z, Wu T (2016) Geochemistry of dissolved trace elements and heavy metals in the Dan River Drainage (China): distribution, sources, and water quality assessment. Environ Sci Pollut Res 23(8):8091-8103. https://doi.org/10.1007/ s11356-016-6074-x

37. Acharya A et al (2020) Chemical characteristics of the Karmanasha river water and Its appropriateness for irrigational usage. J Nepal Chem Soc 41:94-102. https://doi.org/10.3126/jncs.v41i1.30494

38. WHO, "Guidelines for Drinking-water Quality," 2011.

39. Misaghi F, Delgosha F, Razzaghmanesh M, Myers B (2017) Introducing a water quality index for assessing water for irrigation purposes: A case study of the Ghezel Ozan River. Sci Total Environ 589:107-116. https://doi.org/10.1016/j.scitotenv.2017.02.226

40. Vasanthavigar M et al (2010) Application of water quality index for groundwater quality assessment: Thirumanimuttar sub-basin, Tamilnadu, India. Environ Monit Assess 171(1-4):595-609. https:// doi.org/10.1007/s10661-009-1302-1

41. Wu B, Zhao DY, Jia HY, Zhang Y, Zhang XX, Cheng SP (2009) Preliminary risk assessment of trace metal pollution in surface water from Yangtze River in Nanjing section, China. Bull Environ Contam Toxicol 82(4):405-409. https://doi.org/10.1007/ s00128-008-9497-3

42. Epa U (1989) Carcinogen risk assessment. Environ Health Perspect 81:103-105. https://doi.org/10.1289/ehp.8981103

43. Li S, Zhang Q (2010) Spatial characterization of dissolved trace elements and heavy metals in the upper Han River (China) using multivariate statistical techniques. J Hazard Mater 176(1-3):579588. https://doi.org/10.1016/j.jhazmat.2009.11.069

44. Khan S, Cao Q, Zheng YM, Huang YZ, Zhu YG (2008) Health risks of heavy metals in contaminated soils and food crops irrigated with wastewater in Beijing, China. Environ Pollut 152(3):686-692. https://doi.org/10.1016/j.envpol.2007.06.056

45. Chen SC, Liao CM (2006) Health risk assessment on human exposed to environmental polycyclic aromatic hydrocarbons pollution sources. Sci Total Environ 366(1):112-123. https://doi. org/10.1016/j.scitotenv.2005.08.047

46. Towfiqul Islam ARM et al (2020) Quantifying source apportionment, co-occurrence, and ecotoxicological risk of metals from upstream, lower midstream, and downstream river segments, Bangladesh. Environ Toxicol Chem. https://doi.org/10.1002/etc. 4814

47. NDWQS, "Ministry of Physical Planning and Works Singhadarbar kathmandu National Drinking Water Quality Standards , 2005 Implementation Directives for National Drinking Water Quality Standards , 2005 Government of Nepal Notice issued by Ministry of Physical Planni," 2005.

Publisher's Note Springer Nature remains neutral with regard to jurisdictional claims in published maps and institutional affiliations. 